УДК 004:78:005.921.1- 022.324: [002.1:37]

Іванова Світлана Миколаївна

кандидат педагогічних наук, завідувач відділу відкритих освітньо-наукових інформаційних систем Інститут інформаційних технологій і засобів навчання НАПН України, м. Київ, Україна

iv-svetlana@yandex.ua

\title{
ІНФОРМАЦЙНО-АНАЛІТИЧНА ПІДТРИМКА НАУКОВОЇ ДІЯЛЬНОСТІ В ГАЛУЗІ ПЕДАГОГІЧНИХ НАУК
}

\begin{abstract}
Анотація. У статті представлені результати аналізу інструментів інформаційно-аналітичної підтримки, що допомагають удосконалити наукову діяльність у галузі педагогічних наук. Розглянуті процеси наукової діяльності у галузі педагогічних наук та запропонована класифікація інструментів інформаційно-аналітичної підтримки відповідно до цих процесів. Виокремлені переваги електронних систем відкритого доступу на прикладі використання системи Open Journal Systems для ведення електронного фахового видання Інституту інформаційних технологій і засобів навчання Національної академії педагогічних наук України „Інформаційні технології і засоби навчання”. Визначені основні вимоги до системи інформаційно-аналітичної підтримки наукової діяльності у галузі педагогічних наук.
\end{abstract}

Ключові слова: інформаційно-аналітична підтримка; наукова діяльність у галузі педагогічних наук; електронні системи відкритого доступу.

\section{1. ВСТУП}

Постановка проблеми. Стрімкий розвиток інформаційного суспільства, інформаційно-комунікаційних технологій (IКТ), зміни методів збирання, зберігання, передачі та аналітичної обробки відомостей і даних [1] суттєво впливають на вимоги до інструментарію, що забезпечує інформаційно-аналітичну підтримку наукової діяльності, зокрема у галузі педагогічних наук.

Проведення наукової діяльності, процеси пошуку, аналізу та використання наукових здобутків мають забезпечуватись відповідною інформаційно-аналітичною підтримкою, що на практиці доводить актуальність та важливість здійснюваних науково-дослідних робіт.

Відповідно до уточненого поняття інформаційно-аналітичної підтримки наукової діяльності у галузі педагогічних наук у роботі [2], актуальним стає підбір інструментарію для забезпечення умов щодо швидкого обміну відомостей і даних, їх аналізу, синтезу, оцінки та моніторингу згідно з вимогами до діяльності наукового співробітника.

Аналіз останніх досліджень і публікацій. Проблемам створення і використання інформаційно-аналітичних систем присвячені дослідження вітчизняних учених В. Ю. Бикова, Л. В. Головко, С. М. Іванової, Н. Т. Задорожної, Л. А. Лупаренко, О. В. Новицького, В. А. Резніченка, О. Д. Словінської, Д. В. Солов'яненко, О. М. Спіріна, М. А. Шиненка та ін., зарубіжних дослідників Дж. Вілінски (Willinsky, John), Е. Брайн (Edgar, Brian D.) та ін.

Мета статті. Визначити основні вимоги до системи інформаційно-аналітичної підтримки наукової діяльності у галузі педагогічних наук та виокремити інструменти, що їх задовольняють. 


\section{2. РЕЗУЛЬТАТИ ДОСЛІДЖЕННЯ}

Важливим для визначення вимог до системи інформаційно-аналітичної підтримки педагогічних досліджень $є$ :

1) надати характеристику основних процесів наукової діяльності у галузі педагогічних наук, що потребують інформаційно-аналітичної підтримки;

2) виокремити основні інструменти для інформаційно-аналітичної підтримки педагогічних досліджень.

Так, відповідно до Закону «Про наукову і науково-технічну діяльність» [3] до процесів наукової діяльності у галузі педагогічних наук слід віднести:

- написання наукової статті, метою якого є оприлюднення та впровадження наукового досвіду;

- рецензування наукових статей, метою якого є підвищення якості наукових статей, що публікуються в журналі, за допомогою оцінки матеріалів науковими експертами;

- організація та проведення конференції, семінару та ін., метою якого є обмін науковим досвідом, оприлюднення та впровадження наукового досвіду;

- виступ на конференції, семінарі, форумі та ін., метою якого $є$ інформування щодо наукових результатів, обмін досвідом;

- експертиза наукової продукції, метою якого $\epsilon$ здійснення аналізу інноваційності та перспективності наукового дослідження;

- педагогічний експеримент, метою якого є формування психічних якостей, процесів, що досліджуються безпосередньо під час навчальної діяльності;

- ведення науково-педагогічної діяльності, метою якого $\epsilon$ підвищення кваліфікації науково-педагогічних кадрів та самоосвіта.

Варто зазначити, що інструменти для інформаційно-аналітичної підтримки педагогічних досліджень мають, на нашу думку, розглядатися у двох контекстах, а саме, як інструменти інформаційно-комунікаційної підтримки та інструменти аналітичної підтримки.

Так, інформаційно-комунікаційна підтримка наукової діяльності передбачає допомогу та сприяння суб'єктам наукової діяльності в оприлюдненні, розповсюдженні та використанні наукових результатів засобами IКТ [4] та охоплює такі основні інструменти як, наприклад:

- програмні платформи для створення наукових електронних бібліотек (DSpace, EPrints, Koha, Greenstone, GNUTECA, Muselog та ін.);

- веб-технології для сумісної роботи науковців у мережі Інтернет (Google Apps, Google +, Skype, ExpertSystem, ClickWebinar, eTutorium Webinar та ін.);

- програмні системи для проведення дистанційного навчання (Blackboard eEducation platform, Moodle, Web Course Tools, WebTutor, Microsoft Learning Gateway та ін.)

- веб-системи для проведення тестування знань (OpenTest, Test Online, TCExam та ін.);

- прикладне програмне забезпечення для інтерактивного редактора формул (MathType, TeX, Statistics, Maple ma iн.), обробки тексту (WordPerfect, WordPro, Лексикон Works та ін.), створення електронного макета друкованого видання (Adobe Page Maker, Corel Ventura ma iн.), побудови діаграм і графіків (Excel, SuperCalc та ін.) тощо;

- системи для укладання вільних публічних ліцензій (Creative Commons, Berkeley Software Distribution, General Public License, Mozilla Public License, European Union Public License та ін.). 
Аналітична підтримка, що залежить від вимог до оцінювання та моніторингу наукової продукції [5], охоплює такі основні інструменти як, наприклад:

- системи перевірки наукових робіт на плагіат (Plagiarism Checker, AntiPlagiarism, Advego Plagiatus, Double Content Finder, PaperRater та ін.);

- системи індексування наукової продукції (Google Scholar, Web of Science, Scopus, Index Copernicus та ін.);

- системи статистичного аналізу відвідування веб-ресурсу (Google Analytics, Openstat, WaybackMachine та ін.).

Головним чином учені [6-9] акцентують увагу на електронних системах відкритого доступу, що визначаються як програмне забезпечення з відкритим вихідним кодом для ведення рецензованих наукових журналів [9]. Серед цих систем популярними є такі відкриті системи керування журналами відкритого доступу як: Open Journal Systems, DPubS, ePublishing Toolkit, GAPworks, Hyperjournal, Lodel, OpenACS, SOPS, TOPAZ, Scopemed та ін. [8]

Дж. Вілінски, Е. Брайн [8] у 2010 році провели експертне опитування 2,748 редакторів журналів та 3'ясували, що найбільш зручною системою для ведення наукового журналу є Open Journal Systems (OJS). На рисунку 1 представлена діаграма за континентами щодо використання системи $O J S$ для ведення наукових журналів.

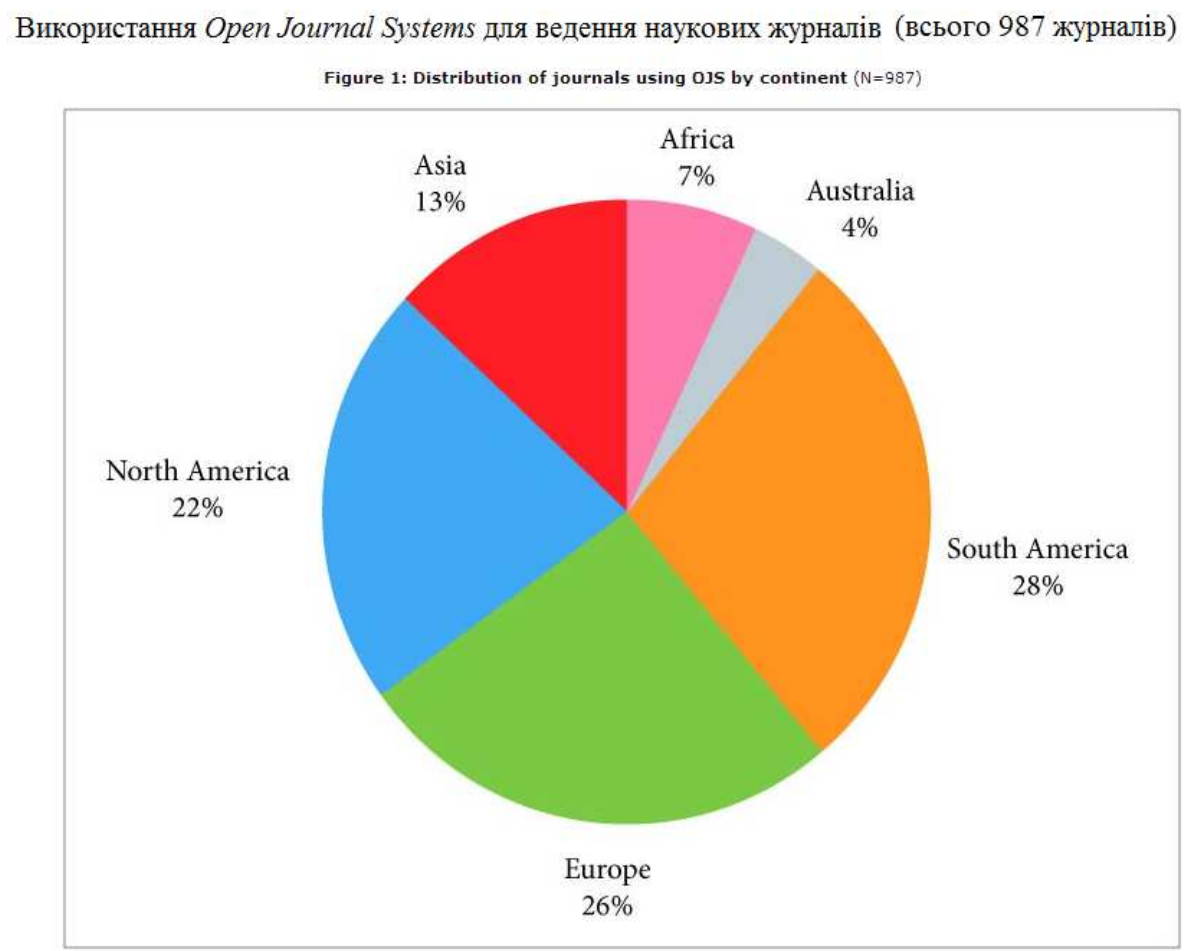

Рис. 1. Діаграма за континентами щуодо використання системи OJS для ведення наукових журналів [8]

Респонденти, які були опитані [8], зазначали, що OJS є інструментом, що може бути підтримкою більшості видів наукової діяльності, ніж інші інструменти, що зазначалися вище.

Розглянемо, які інструменти інформаційно-аналітичної підтримки можуть використовуватися відповідно до певних процесів наукової діяльності у галузі педагогічних наук. 
У таблиці 1 класифіковані інструменти інформаційно-аналітичної підтримки відповідно до процесів наукової діяльності у галузі педагогічних наук.

Табличя 1.

\section{Класифікація інструментів інформаційно-аналітичної підтримки відповідно до процесів наукової діяльності у галузі педагогічних наук}

\begin{tabular}{|c|c|c|}
\hline $\begin{array}{l}\text { Процеси наукової } \\
\text { діяльності у галузі } \\
\text { педагогічних наук }\end{array}$ & Підпроцеси & $\begin{array}{l}\text { Інструменти інформаційно- } \\
\text { аналітичної підтримки }\end{array}$ \\
\hline \multirow[t]{6}{*}{$\begin{array}{l}\text { 1. Написання } \\
\text { наукової статті }\end{array}$} & $\begin{array}{l}\text { 1.1. Формування проблеми; } \\
\text { 1.1.1. Формулювання теми; } \\
\text { 1.1.2. Визначення об'єкту та предмету; } \\
\text { 1.1.3. Формулювання мети; } \\
\text { 1.1.4. Визначення завдань. }\end{array}$ & $\begin{array}{l}\text { веб-технологї для сумісної } \\
\text { роботи науковців у мережі } \\
\text { Інтернет; пошукові системи } \\
\text { мережі Інтернет, програми } \\
\text { пакету Мicrosoft Office, } \\
\text { електронні системи відкритого } \\
\text { доступу, програмні платформи } \\
\text { для створення наукових } \\
\text { електронних бібліотек, }\end{array}$ \\
\hline & $\begin{array}{l}\text { 1.2. Аналіз літератури з проблеми дослідження; } \\
\text { 1.2.1. Формування рубрикатора понять } \\
\text { дослідження; } \\
\text { 1.2.2 Аналіз визначень понять досліджуваної } \\
\text { проблеми; } \\
\text { 1.2.3. Аналіз наукових підходів до } \\
\text { досліджуваної проблеми; }\end{array}$ & $\begin{array}{l}\text { веб-технологї̈ для сумісної } \\
\text { роботи науковців у мережі } \\
\text { Інтернет; пошукові системи } \\
\text { мережі Інтернет, програми } \\
\text { пакету Microsoft Office }\end{array}$ \\
\hline & 1.3. Визначення методики дослідження; & $\begin{array}{l}\text { пошукові системи мережі } \\
\text { Інтернет, електронні системи } \\
\text { відкритого доступу, програми } \\
\text { пакету Microsoft Office, } \\
\text { прикладне програмне } \\
\text { забезпечення }\end{array}$ \\
\hline & $\begin{array}{l}\text { 1.4. Виклад особистих результатів дослідження; } \\
\text { 1.4.1. Класифікація результатів дослідження; } \\
\text { 1.4.2. Зведення результатів у таблиці, схеми, } \\
\text { діаграми. }\end{array}$ & $\begin{array}{l}\text { програми пакету Microsoft } \\
\text { Office, прикладне програмне } \\
\text { забезпечення, веб-технології } \\
\text { для сумісної роботи науковців у } \\
\text { мережі Інтернет }\end{array}$ \\
\hline & $\begin{array}{l}\text { 1.5. Написання висновків та визначення } \\
\text { перспектив подальших досліджень. }\end{array}$ & $\begin{array}{l}\text { програми пакету Microsoft } \\
\text { Office, прикладне програмне } \\
\text { забезпечення }\end{array}$ \\
\hline & $\begin{array}{l}\text { 1.6. Публікація статті; } \\
\text { 1.6.1. Відправлення статті до редакційної } \\
\text { колегії; } \\
\text { 1.6.2. Отримання зауважень рецензентів; } \\
\text { 1.6.3. Опрацювання та аналіз зауважень; } \\
\text { 1.6.4. Виправлення помилок згідно зробленим } \\
\text { зауваженням; } \\
\text { 1.6.5. Відправлення до редакції виправленої } \\
\text { статті. }\end{array}$ & $\begin{array}{l}\text { системи перевірки наукових } \\
\text { робіт на плагіат, електронні } \\
\text { системи відкритого доступу, } \\
\text { веб-технології для сумісної } \\
\text { роботи науковців у мережі } \\
\text { Інтернет }\end{array}$ \\
\hline
\end{tabular}




\begin{tabular}{|c|c|c|}
\hline & $\begin{array}{l}\text { 1.7. Оприлюднення-внесення статті у відкритий } \\
\text { доступ; } \\
\text { 1.7.1. Відстеження цитувань статті; } \\
\text { 1.7.2. Аналіз актуальності матеріалу статті; } \\
\text { 1.7.3. Виокремлення нової проблеми. }\end{array}$ & $\begin{array}{l}\text { електронні системи відкритого } \\
\text { доступу, системи індексування } \\
\text { наукової продукції, системи } \\
\text { статистичного аналізу } \\
\text { відвідування веб-ресурсу, } \\
\text { системи для укладання вільних } \\
\text { публічних ліцензій }\end{array}$ \\
\hline \multirow[t]{5}{*}{$\begin{array}{l}\text { 2. Рецензування } \\
\text { наукових статей }\end{array}$} & 2.1. Отримання статті для рецензування. & $\begin{array}{l}\text { електронні системи відкритого } \\
\text { доступу, веб-технології для } \\
\text { сумісної роботи науковців у } \\
\text { мережі Інтернет }\end{array}$ \\
\hline & $\begin{array}{l}\text { 2.2. Оцінка змісту статті: викладені в статті } \\
\text { наукові положення та результати, новизна } \\
\text { наукових положень і результатів; } \\
\text { обгрунтованість наукових положень і } \\
\text { результатів; значимість наукових положень і } \\
\text { результатів. }\end{array}$ & \multirow[t]{4}{*}{$\begin{array}{l}\text { системи перевірки наукових } \\
\text { робіт на плагіат, системи } \\
\text { відкритого доступу, веб- } \\
\text { технології для сумісної роботи } \\
\text { науковців у мережі Інтернет, } \\
\text { електронні системи відкритого } \\
\text { доступу }\end{array}$} \\
\hline & $\begin{array}{l}\text { 2.3. Зауваження по викладу й оформленню } \\
\text { матеріалу статті. }\end{array}$ & \\
\hline & 2.4. Пропозиції з доопрацювання тексту. & \\
\hline & 2.5. Висновок про можливість публікації статті. & \\
\hline \multirow[t]{2}{*}{$\begin{array}{l}\text { 3. Організація та } \\
\text { проведення } \\
\text { конференції, } \\
\text { семінару та ін. }\end{array}$} & $\begin{array}{l}\text { 3.1. Технічний контекст } \\
\text { 3.1.1. Розробка програми конференції; } \\
\text { 3.1.2. Затвердження і запрошення спікерів; } \\
\text { 3.1.3. Вибір місця проведення; } \\
\text { 3.1.4. Організація банкетної частини; } \\
\text { 3.1.5. Організація технічного оснащення; } \\
\text { 3.1.6. Транспортне забезпечення та розміщення. }\end{array}$ & \multirow[t]{2}{*}{$\begin{array}{l}\text { системи відкритого доступу, } \\
\text { веб-технології для сумісної } \\
\text { роботи науковців у мережі } \\
\text { Інтернет, електронні системи } \\
\text { відкритого доступу }\end{array}$} \\
\hline & $\begin{array}{l}\text { 3.2. Науковий контекст } \\
\text { 3.2.1. Визначення наукових секцій; } \\
\text { 3.2.2. Відбір доповідей; } \\
\text { 3.2.3. Відбір тез та статей; } \\
\text { 3.2.4. Проведення круглих столів; } \\
\text { 3.2.5. Підведення підсумків. }\end{array}$ & \\
\hline \multirow[t]{2}{*}{$\begin{array}{l}\text { 4. Наукова } \\
\text { доповідь }\end{array}$} & $\begin{array}{l}\text { 4.1. Технічний контекст; } \\
\text { 4.1.1. Створення презентації, доповіді } \\
\text { 4.1.2. Створення наочності для доповіді. }\end{array}$ & $\begin{array}{l}\text { програми пакету Microsoft } \\
\text { Office, прикладне програмне } \\
\text { забезпечення }\end{array}$ \\
\hline & $\begin{array}{l}\text { 4.2. Науковий контекст } \\
\text { 4.2.1. створення плану доповіді; } \\
\text { 4.2.2. виклад наукової проблеми; } \\
\text { 4.2.3. визначення висновків та пропозицій. }\end{array}$ & $\begin{array}{l}\text { програми пакету Microsoft } \\
\text { Office, прикладне програмне } \\
\text { забезпечення, системи } \\
\text { відкритого доступу, веб- } \\
\text { технології для сумісної роботи } \\
\text { науковців у мережі Інтернет, } \\
\text { системи для укладання вільних } \\
\text { публічних ліцензій }\end{array}$ \\
\hline $\begin{array}{l}\text { 5. Експертиза } \\
\text { наукової продукції }\end{array}$ & $\begin{array}{l}\text { 5.1. Здійснення науково-дослідної, } \\
\text { інформаційно-аналітичної та організаційно- } \\
\text { методичної діяльності у сфері наукової } \\
\text { експертизи/ } \\
\text { 5.2. Надання зауважень та пропозицій щодо } \\
\text { проведеної роботи; }\end{array}$ & $\begin{array}{l}\text { програми пакету Microsoft } \\
\text { Office, прикладне програмне } \\
\text { забезпечення, системи } \\
\text { відкритого доступу, веб- } \\
\text { технології для сумісної роботи } \\
\text { науковців у мережі Інтернет, }\end{array}$ \\
\hline
\end{tabular}




\begin{tabular}{|c|c|c|}
\hline & $\begin{array}{l}\text { 5.3. Оцінювання новизни наукового } \\
\text { дослідження; } \\
\text { 5.4. Надання незалежної та об’єктивної оцінки } \\
\text { щодо проведеної або запропонованої роботи; } \\
\text { 5.5. Аналіз науково-дослідної роботи щодо її } \\
\text { актуальності; } \\
\text { 5.6. Визначення науково-теоретичної, } \\
\text { соціальної та практичної значущості роботи. }\end{array}$ & $\begin{array}{l}\text { системи перевірки наукових } \\
\text { робіт на плагіат, електронні } \\
\text { системи відкритого доступу }\end{array}$ \\
\hline $\begin{array}{l}\text { 6. Педагогічна } \\
\text { діяльність }\end{array}$ & $\begin{array}{l}\text { 6.1. Проведення методичної роботи; } \\
\text { 6.2. Проектування та створення навчальних } \\
\text { курсів; } \\
\text { 6.3. Ведення навчальних курсів; } \\
\text { 6.4. Проведення форумів, семінарів, } \\
\text { консультацій та ін. }\end{array}$ & $\begin{array}{l}\text { прикладне програмне } \\
\text { забезпечення, веб-технології } \\
\text { для сумісної роботи науковців у } \\
\text { мережі Інтернет, програмні } \\
\text { платформи для створення } \\
\text { наукових електронних } \\
\text { бібліотек, системи для } \\
\text { укладання вільних публічних } \\
\text { ліцензій, електронні системи } \\
\text { відкритого доступу }\end{array}$ \\
\hline \multirow[t]{3}{*}{$\begin{array}{l}\text { 7. Педагогічний } \\
\text { експеримент }\end{array}$} & $\begin{array}{l}\text { 7.1. Підготовчий етап } \\
\text { 7.1.1. Вивчення стану розвитку галузі освіти на } \\
\text { етапі проведення дослідження; } \\
\text { 7.1.2. Виявлення актуальних проблем, які } \\
\text { вимагають вирішення за допомогою } \\
\text { експерименту; } \\
\text { 7.1.3. Постановка проблеми дослідження, } \\
\text { визначення предмета та об’єкта дослідження; } \\
\text { 7.1.4. Вивчення науково-методичної літератури } \\
\text { з проблеми дослідження; } \\
\text { 7.1.5. Визначення цілей і завдань, побудова } \\
\text { гіпотез, програми експерименту; } \\
\text { 7.1.6. Пошук шляхів розв’язання проблеми: } \\
\text { підбір методів, розробка методики. }\end{array}$ & $\begin{array}{l}\text { програми пакету Microsoft } \\
\text { Office, прикладне програмне } \\
\text { забезпечення, системи } \\
\text { відкритого доступу, веб- } \\
\text { технології для сумісної роботи } \\
\text { науковців у мережі Інтернет, } \\
\text { пошукові системи мережі } \\
\text { Інтернет, системи для } \\
\text { укладання вільних публічних } \\
\text { ліцензій }\end{array}$ \\
\hline & $\begin{array}{l}\text { 7.2. Дослідницький етап } \\
\text { 7.2.1. Констатувальний експеримент, } \\
\text { направлений на встановлення фактичного стану } \\
\text { та рівня психолого-педагогічних особливостей } \\
\text { контингенту на момент проведення } \\
\text { дослідження; }\end{array}$ & $\begin{array}{l}\text { веб-технології для сумісної } \\
\text { роботи науковців у мережі } \\
\text { Інтернет, пошукові системи } \\
\text { мережі Інтернет, прикладне } \\
\text { програмне забезпечення }\end{array}$ \\
\hline & $\begin{array}{l}\text { 7.2.2. Формувальний експеримент, спрямований } \\
\text { на вивчення психолого-педагогічного явища } \\
\text { безпосередньо в процесі спеціально } \\
\text { організованого експериментального навчання } \\
\text { та виховання, активного формування тих чи } \\
\text { інших психолого-педагогічних особливостей; } \\
\text { 7.2.3. Контрольний експеримент, що } \\
\text { проводиться після того, як отримані результати } \\
\text { формувального експерименту з групою } \\
\text { респондентів такого ж віку, які знаходяться в } \\
\text { подібних умовах навчання та виховання, але з } \\
\text { ними не проводили формувальний експеримент } \\
\text { 7.3. Обробка даних дослідження. } \\
\text { 7.3.1. Використання статистичних прийомів, } \\
\text { формул, способів кількісних розрахунків та } \\
\text { основних положень теорії ймовірностей з } \\
\text { метою узагальнення, зведення в систему, } \\
\text { виявлення прихованих закономірностей серед } \\
\text { кількісних показників, що отримані в ході }\end{array}$ & $\begin{array}{l}\text { веб-технології для сумісної } \\
\text { роботи науковців у мережі } \\
\text { Інтернет, пошукові системи } \\
\text { мережі Інтернет, прикладне } \\
\text { програмне забезпечення }\end{array}$ \\
\hline
\end{tabular}




\begin{tabular}{|l|l|l|}
\hline & експерименту & $\begin{array}{l}\text { програми пакету Microsoft } \\
\text { Office, прикладне програмне } \\
\text { забезпечення }\end{array}$ \\
\cline { 2 - 3 } & $\begin{array}{l}\text { 7.4. Інтерпретація даних дослідження та } \\
\text { 7.5. Впровадження результатів експерименту. }\end{array}$ & $\begin{array}{l}\text { системи відкритого доступу, } \\
\text { веб-технологї для сумісної } \\
\text { роботи науковців у мережі } \\
\text { Інтернет, електронні системи } \\
\text { відкритого доступу }\end{array}$ \\
\hline
\end{tabular}

3 огляду на наведену вище таблицю 1, слід звернути увагу на те, що системи відкритого доступу є важливими інструментами інформаційно-аналітичної підтримки процесів наукової діяльності у галузі педагогічних наук.

Відповідно до визначених процесів наукової діяльності у галузі педагогічних наук, до системи інформаційно-аналітичної підтримки можуть бути запропоновані такі вимоги:

- вільний доступ до відомостей і даних;

- забезпечення розширеного пошуку ресурсів;

- забезпечення зручного форматування наукового тексту;

- підтримка сумісної роботи науковців;

- підтримка наукового інформаційного обміну суб’єктів наукової діяльності у галузі педагогічних наук;

- забезпечення оцінювання та моніторингу наукової продукції;

- забезпечення зручної системи рецензування наукової продукції;

- забезпечення підтримки педагогічної діяльності науковців;

- забезпечення конфіденційності;

- підтримка авторських прав.

Наведемо приклади використання Open Journal Systems на досвіді ведення електронного фахового видання Інституту інформаційних технологій і засобів навчання Національної академії педагогічних наук України „Інформаційні технології і засоби навчання" (http://journal.iitta.gov.ua).

На рисунку 2 представлено фрагмент сайту електронного фахового видання «Інформаційні технології і засоби навчання», на якому пронумеровані основні інструменти інформаційно-аналітичної підтримки діяльності науковців.

На головній сторінці сайту вказані деякі основні інструменти інформаційноаналітичної підтримки відповідно до процесів наукової діяльності у галузі педагогічних наук, а саме:

1- пошукова система, зокрема розширений пошук за автором;

2- підтримка наукового інформаційного обміну різним категоріям користувачів електронного фахового видання, яка надає такі можливості [10]:

а) авторам: розповсюдження та оприлюднення наукових робіт, їх індексація та цитування; підвищення власного рейтингу в своїй науковій галузі; можливість додавання до основного тексту статті супутнього контенту (графічних компонентів, презентацій, аудіо- та відеоматеріалів та ін.);

б) читачам: безкоштовний доступ до публікацій, даних, відомостей; наявність пошукових інструментів за багатьма категоріями; можливість завантаження необхідного матеріалу в електронному вигляді, для подальшої обробки, копіювання та ін.; налагодження безпосереднього контакту користувача 3 автором статті; 
в) видавиям: оперативність підготовки і публікації статті; автоматизація процесів рецензування, редагування та підтримки користувачів; здійснення редакційно-видавничих завдань дистанційно;

г) науковим установам: впровадження новітніх технологій у робочий процес; підвищення ефективності наукової діяльності співробітників; підвищення конкурентоспроможності та престижності установи;

д) бібліотекам: задоволення інформаційних потреб читачів; спрощення процесів каталогізації, управління, індексації та рейтингового оцінювання;

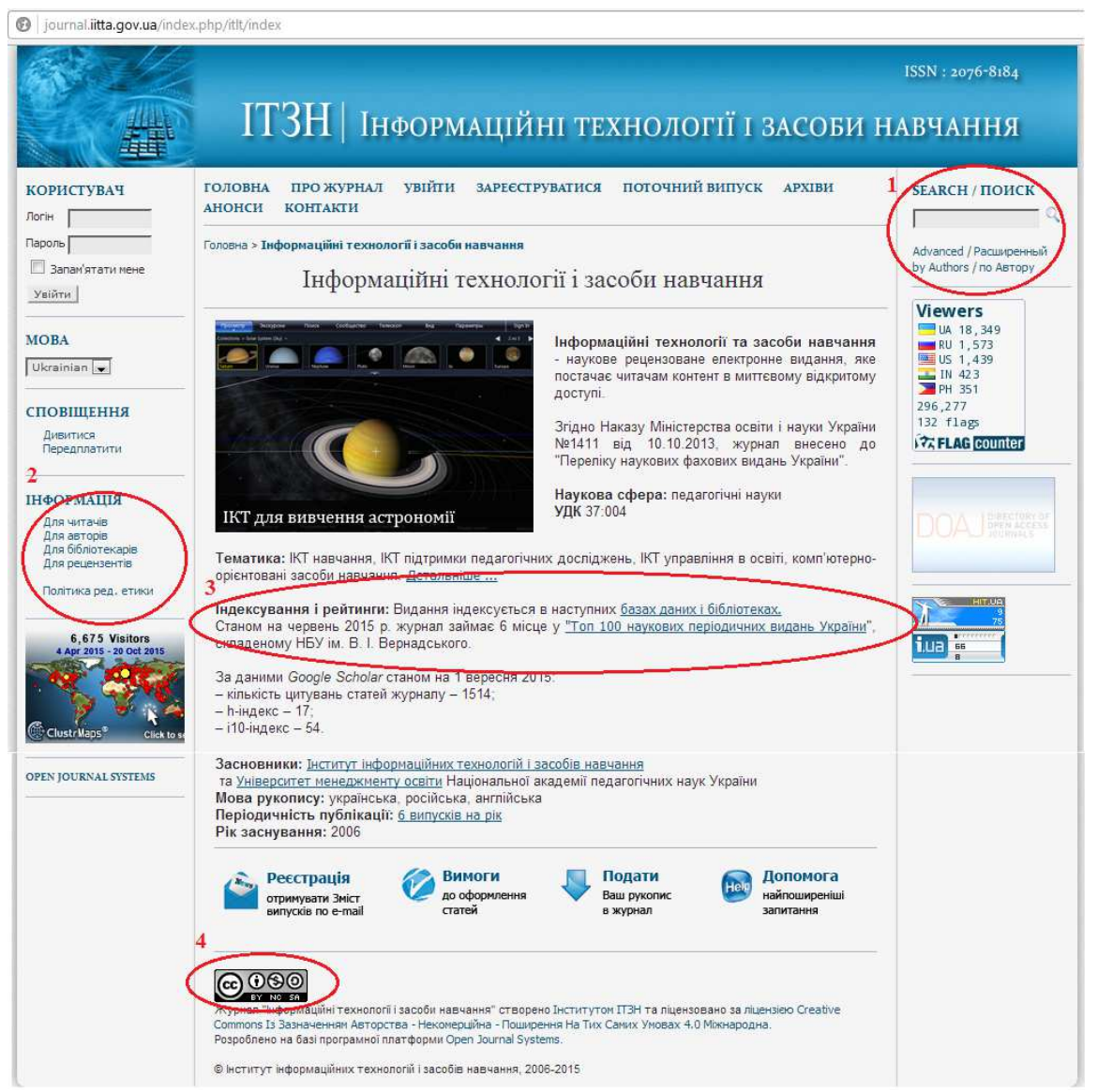

Рис. 2. Фрагмент сайту електронного фахового видання «Інформаційні технології $і$ засоби навчання» [11];

3- аналітична підтримка, що представлена, наприклад, системами веб-аналітики

4- системи для укладання вільних публічних ліцензій.

\section{3. ВИСНОВКИ ТА ПЕРСПЕКТИВИ ПОДАЛЬШИХ ДОСЛІДЖЕНЬ}

Інформаційно-аналітична підтримка педагогічних досліджень включає в себе широкий набір інструментального супроводу та набуває широкого застосування в науковій діяльності установ.

Система Open Journal Systems є важливим інструментом інформаційноаналітичної підтримки наукової діяльності, зокрема у галузі педагогічних наук. Відкритий і вільний доступ до наукових публікацій в журнальній системі дозволяє 
підвищити цитованість науковців. Ця система використовується у вищих навчальних закладах, наукових установах та ін.

Вимоги до системи інформаційно-аналітичної підтримки окреслюють подальші перспективи дослідження щодо підбору інструментів системи інформаційноаналітичної підтримки наукової діяльності у галузі педагогічних наук.

\title{
СПИСОК ВИКОРИСТАНИХ ДЖЕРЕЛ
}

1. Основні засади розвитку інформаційного суспільства в Україні на 2007-2015 роки [Електронний ресурс] / [затвердж. Законом України від 9 січ. 2007 p. No537-V] // Веб-портал Верховної Ради України. - Режим доступу: http://zakon2.rada.gov.ua/laws/show/537-16\#n14.

2. Іванова С.М. Наукова електронна бібліотека НАПН України як засіб інформаційно-аналітичної підтримки педагогічних досліджень / С.М. Іванова // Комп’ютер у школі та сім’ї. - 2015 - № 6- С. $11-15$.

3. Закон України „Про наукову і науково-технічну діяльність” (Відомості Верховної Ради України (BВP), 1992, N 12, ст.165) [Електронний ресурс] - Режим доступу: http://zakon2.rada.gov.ua/laws/show/1977-12. - дата доступу 2010.

4. Іванова С.М. Використання системи EPrints як засобу інформаційно-комунікаційної підтримки наукової діяльності в галузі педагогічних наук: автореф. дис. на здобуття наук. ступеня канд. пед. наук: спец. 13.00.10 “Інформаційно-комунікаційні технології в освіті” / С.М. Іванова. - Київ, 2015 $-20 \mathrm{c}$.

5. Спірін О.М. Інформаційно-комунікаційні технології моніторингу впровадження результатів науково-дослідних робіт / О.М. Спірін // Інформаційні технології і засоби навчання - 2013. - № 4 (36). - Режим доступу: http://journal.iitta.gov.ua.

6. Головко Л. В. Перспективи використання Open Journal Systems у бібліотеках ВНЗ України System [Електронний ресурс]. - Режим доступу : http://www.library.univ.kiev.ua/ukr/for_lib/konf2012/10.pdf

7. Соловяненко Д. В. Модель общегосударственной платформы научной периодики на базе Open Journals System [Електронний pecypc]. - Режим доступу : http://archive.nbuv.gov.ua/articles/2011/11sdvojs.pdf.

8. Edgar, Brian D., \& Willinsky, John. A Survey of the Scholarly Journals Using Open Journal Systems / Scholarly and Research Communication. 2010. - Vol 1, № 2. - 22 pp. [online]. - Available from : http://src-online.ca/index.php/src/article/view/24/41

9. Лупаренко Л. А. Передумови переходу електронного наукового фахового видання на платформу Open Journal Systems / Л. А. Лупаренко // Звітна наукова конференція Інституту інформаційних технологій і засобів навчання НАПН України : Матеріали наукової конференції. - Київ : IITЗН НАПН України, 2011. -c. 59-60

10. Яцишин А. В. Соціально-психологічні аспекти забезпечення відкритого доступу з використанням електронних журнальних систем / А. В. Яцишин, Л. А. Лупаренко //Вісник Житомирського державного університету. - 2013 .- № 4 (70). Педагогічні науки. - с. 69 - 74

11. Сороко Н.В., Шиненко М.А. Моніторинг електронних освітньо-наукових ресурсів за допомогою Google Analytics / Хмарні технології в освіті: матеріали Всеукраїнського науково-методичного Інтернет-семінару (Кривий Ріг-Київ-Черкаси-Харків, 21 грудня 2012 р.).- Кривий Ріг: Видавничий відділ КМІ, 2012.-173 с., с.95.

\section{ИНФОРМАЦИОННО-АНАЛИТИЧЕСКАЯ ПОДДЕРЖКА НАУЧНОЙ ДЕЯТЕЛЬНОСТИ В ОБЛАСТИ ПЕДАГОГИЧЕСКИХ НАУК}

\author{
Иванова Светлана Николаевна \\ кандидат педагогических наук, \\ заведующая Отделом открытых образовательно-научных информационных систем \\ Институт информационных технологий и средств обучения НАПН Украины, г. Киев, Украина \\ iv-svetlana@yandex.ua
}




\begin{abstract}
Аннотация. В статье представлены результаты анализа инструментов информационноаналитической поддержки, которые помогают усовершенствовать научную деятельность в области педагогических наук. Рассмотрены процессы научной деятельности в области педагогических наук и предложена классификация инструментов информационноаналитической поддержки в соответствии с этими процессами. Выделены преимущества электронных систем открытого доступа на примере использования системы Open Journal Systems для ведения электронного профессионального издания Института информационных технологий и средств обучения Национальной академии педагогических наук Украины „Информационные технологии и средства обучения”. Определены основные требования к системе информационно-аналитической поддержки научной деятельности в области педагогических наук.
\end{abstract}

Ключевые слова: информационно-аналитическая поддержка; научная деятельность в области педагогических наук; электронные системы открытого доступа.

\title{
INFORMATION AND ANALYTICAL SUPPORT FOR SCIENTIFIC ACTIVITIES IN THE FIELD OF EDUCATIONAL SCIENCES
}

\author{
Svitlana M. Ivanova \\ $\mathrm{PhD}$ (in Pedagogic), head of the Department of Open Education and Scientific Information Systems \\ Institute of Information Technologies and Learning Tools of NAESof Ukraine, Kyiv, Ukraine \\ iv-svetlana@yandex.ua
}

\begin{abstract}
The article deals with the results of the analysis of information and analytical support tools which help to improve scientific activity in the field of educational sciences. The processes of scientific activity in the field of educational sciences are considered, as well as classification of information and analytical support tools using in these processes are proposed. The benefits of open access electronic systems are singled out by the example of electronic professional edition "Information Technologies and Learning Tools" based on the platform of Open Journal Systems and published by the Institute of Information Technologies and Learning Tools of National Academy of Educational Sciences of Ukraine. The basic requirements to information and analytical support of scientific activity in the field of educational sciences are determined.
\end{abstract}

Keywords: information and analytical support; scientific activities in the field of educational sciences; electronic open access systems.

\section{REFERENCES (TRANSLATED AND TRANSLITERATED)}

1. Basic Principles of Information Society in Ukraine for 2007-2015 [online] / [zatverdzh. Law of Ukraine on January 9. 2007 r. No537-V] // Web Portal Verkhovna Rada of Ukraine. - Available from : http://zakon2.rada.gov.ua/laws/show/537-16\#n14. (in Ukrainian).

2. Ivanova S.M. Scientific Electronic Library NAES Ukraine as a means of information and analytical support educational research / S.M. Ivanova // Computer in school and family. - 2015 - № 6- P. 11-15.

3. The Law of Ukraine,, On scientific and technical activity "(Supreme Council of Ukraine (VVR), 1992, N 12, 165) [online] — Available from : http://zakon2.rada.gov. ua / laws / show / 1977-12. - Date Access 2010. (in Ukrainian).

4. Ivanova S. M. The Using of EPrints System as a Tool for Communication and Information Support of Scientific Activities in the Field of Pedagogical Sciences. / S.M. Ivanova - Thesis for the Candidate of Pedagogical Sciences Degree, specialty 13.00.10 - Information and Communication Technologies in Education. - Institute of Information Technologies and Learning Tools of NAPS of Ukraine, Kyiv, 201520 p. (in Ukrainian).

5. Spirin O.M. Information and communication technologies of monitoring implementation of the results of scientific research [online] / O.M. Spirin // Information technologies and learning tools. - 2013. - № 4 (36).- Available from : http://journal.iitta.gov.ua. (in Ukrainian)

6. Golovko L. Prospects for Open Journal Systems Universities in libraries of Ukraine [online]. —Available from : http://www.library.univ.kiev.ua/ukr/for_lib/konf-2012/10.pdf. (in Ukrainian) 
7. Solovyanenko D. V. Model of national platform of scientific periodicals at the Open Journals System [online]. - Available from : http://archive.nbuv.gov.ua/articles/2011/11sdvojs.pdf. (in Russian).

8. Edgar, Brian D., \& Willinsky, John. A Survey of the Scholarly Journals Using Open Journal Systems [online] / Scholarly and Research Communication. 2010. - Vol 1, № 2. - 22 pp. — Available from : http://src-online.ca/index.php/src/article/view/24/41. (in English).

9. Luparenko L.A. Background of transition electronic scientific professional publication on a platform Open Journal Systems / L.A. Luparenko // Reports Scientific Conference of the Institute of Information Technologies and learning tools NAES Ukraine: Conference Materials. - Kyiv, Ukraine IITZN NAES, 2011. - p. 59-60.(in Ukrainian).

10. Yatsyshyn A.V. Socio-psychological aspects of open access journal using electronic systems / A.V. Yatsyshyn, L.A. Luparenko // Bulletin Zhytomyr State University. - 2013 .- № 4 (70).Pedagogichni nauki. -p. 69 - 74.(in Ukrainian).

11. Soroko N.V., Shynenko M.A. Monitoring of electronic educational and scientific resources through Google Analytics / Cloud technology in education materials Ukrainian scientific-methodical Internetseminar (Kryvyi Rih, Kyiv-Cherkasy, Kharkiv, December 21, 2012) .- Krivoy Rog: KMI Publishing Division, 2012 .-173 p., p.95. (in Ukrainian).

\section{(cc) BY-NC-SA}

This work is licensed under Creative Commons Attribution-NonCommercial-ShareAlike 4.0 International License. 